\title{
Efficiency of use of the solid-state YAG: Nd- Laser for hardening of high-strength cast iron VCH 70-3
}

\author{
Maxim Ivanov ${ }^{1, *}$, Oleg Burlachenko ${ }^{1}$, and Alexandr Lyashenko $^{1}$ \\ ${ }^{1}$ Volgograd State Technical University, Department of Construction Production Technology, Avenue \\ V.I. Lenin, 28, 400005, Volgograd, Russia
}

\begin{abstract}
The method to increase the durability of high-strength cast iron with spherical graphite YAG:Nd-laser radiation is proposed. The results of studies in laser processing of cylindrical samples of high-strength cast iron grade of the VCH 70-3 are presented by the YAG:Nd-laser, working in pulse-periodic mode. Effect of the treatment with $1 \mathrm{~kW}$ YAG:Nd-laser on microhardness of high-strength cast iron has been investigated. More effective laser strengthening is found to be occurred by YAG:Nd-laser processing as compared with continuous $\mathrm{CO}_{2}$-laser one. The results showed that when processing of cast iron in general, the zone of laser influence consists of the reflow zone and the zone of quenching from the solid state. The optimal values of parameters of the hardened layer in the radiation by the solid-state YAG:Nd laser are considered. It is shown that under fluence of laser radiation fluence more than $28 \mathrm{j} / \mathrm{mm}^{2}$ is occured the surface melting of cast iron.
\end{abstract}

\section{Introduction}

The processes occurring in the surface layers of cast irons by laser processing, repeatedly theoretically and experimentally investigated [1-10], but attempts to use laser processing for hardening of details from high-strength cast iron with spherical graphite $\mathrm{VCH}$ 70-3 were not always successful. Foundry properties of high-strength cast iron grades of the VCH differ from properties of usual gray cast iron grades of the $\mathrm{SCH}$ a little. Foundry shrinkage of high-strength cast iron is equal to $1,0-1,25 \%$, but in the presence of a free cementite increases up to $1,75 \%$; fluidity is the same, as in gray cast iron [11-14]. High-strength cast iron rather well gives in to machining. In work [15] it was established that after radiation by the continuous $\mathrm{CO}_{2}$-laser the microhardness of the surface layer of high-strength cast iron increases till 6-10 HPA, however it is known, also, that for surface hardening of steels and aluminum is more effective is use of the YAG:Nd-laser, than $\mathrm{CO}_{2}$-laser of the same capacity [16-17].

\footnotetext{
* Corresponding author: clevermax18@mail.ru
} 
Solid state Nd-lasers work from an active element in the form of a core or plate in intermittent and continuous modes [18-20]. For surface hardening of metal, it is preferable to use solid state Nd-lasers. In this work the possibility of use of the YAG:Nd-laser of average power $(1,0 \mathrm{~kW})$ for surface processing of details from high-strength cast iron with spherical graphite VCH 70-3 is investigated.

\section{Main part}

The laser set is intended for surface hardening of metal, contains in quality of basic elements the laser with power supply unit, an optical system for transportation and focusing of the laser beam, system of positioning of the workpiece, a control system and monitoring of parameters of processing [21-26].

The laser processing of cylindrical samples of high-strength cast iron grade of the $\mathrm{VCH}$ 70-3 (3,60 C, 2,7 Si, 0,7 Mn, 0,02 S, 0,1 R, rest is Fe) with a diameter of $24 \mathrm{~mm}$ and a length of $15 \mathrm{~mm}$ was made by the YAG:Nd-laser working in pulse-periodic mode with a frequency of following of pulses of $150 \mathrm{~Hz}$ at the density of power from 1 to $4 \mathrm{~kW} / \mathrm{cm}^{2}$. The diameter of the laser spot on the sample surface was $4 \mathrm{~mm}$. Processing was subjected to "pure samples", the surface of which is washed with water, and the samples coated at $60^{\circ}$ with a coverage of $10-20 \%$ solution of ammonium persulfate, which reduces the reflection coefficient of the laser radiation. In tables 1 and 2 presents the values of the mechanical properties of cast irons and the recommended chemical composition and heat processing of cast iron.

Table 1. Mechanical properties of cast irons.

\begin{tabular}{|l|l|l|l|l|}
\hline $\begin{array}{l}\text { Grade of } \\
\text { cast iron }\end{array}$ & $\begin{array}{l}\text { The limit of the } \\
\text { tensile strength } \\
(\mathrm{kgf} / \mathrm{mm})\end{array}$ & Relative lengthening, $\%$ & $\begin{array}{l}\text { Impact strength, } \\
\mathrm{kg} \bullet \mathrm{cm}^{-\mathrm{cm}^{2}}\end{array}$ & $\begin{array}{l}\text { Hardness, } \\
\mathrm{HB}\end{array}$ \\
\hline VCH 38-17 & 38 & 17 & 6,0 & $140-170$ \\
\hline VCH 42-12 & 42 & 12 & 4,0 & $140-200$ \\
\hline VCH 45-5 & 45 & 5 & 3,0 & $160-220$ \\
\hline VCH 50-2 & 50 & 2 & 2,0 & $180-260$ \\
\hline VCH 60-2 & 60 & 2 & 2,0 & $200-280$ \\
\hline VCH 70-3 & 70 & 3 & 3,0 & $229-275$ \\
\hline VCH 80-3 & 80 & 3 & 2,0 & $220-300$ \\
\hline VCH 100-4 & 100 & 4 & 3,0 & $302-369$ \\
\hline VCH 120-4 & 120 & 4 & 3,0 & $302-369$ \\
\hline
\end{tabular}

Table 2. The recommended chemical composition and heat processing of cast iron

\begin{tabular}{|c|c|c|c|c|c|c|c|c|c|c|c|c|c|}
\hline \multirow{4}{*}{$\begin{array}{l}\text { Grade } \\
\text { of } \\
\text { cast } \\
\text { iron }\end{array}$} & \multicolumn{12}{|c|}{ Mass fraction of elements } & \multirow{4}{*}{$\begin{array}{l}\text { Recommended } \\
\text { heat } \\
\text { processing }\end{array}$} \\
\hline & $\mathrm{C}$ & & & $\mathrm{Si}$ & & & $\mathrm{Mn}$ & $\mathrm{P}$ & $\mathrm{S}$ & $\mathrm{Cr}$ & $\mathrm{Cu}$ & $\mathrm{Ni}$ & \\
\hline & \multicolumn{6}{|c|}{ Wall thickness, mm } & & & & & & & \\
\hline & $\begin{array}{l}\text { to } \\
50\end{array}$ & $\begin{array}{l}50- \\
100\end{array}$ & $>100$ & $\begin{array}{l}\text { to } \\
50\end{array}$ & $\begin{array}{l}50- \\
100\end{array}$ & $>100$ & & \multicolumn{5}{|c|}{ No more } & \\
\hline $\begin{array}{l}\mathrm{VCH} \\
35\end{array}$ & $\begin{array}{l}3,3 \\
- \\
3,8\end{array}$ & $\begin{array}{l}3,0 \\
- \\
3,5\end{array}$ & $\begin{array}{l}2,7- \\
3,2\end{array}$ & $\begin{array}{l}1,9 \\
- \\
2,9\end{array}$ & $\begin{array}{l}1,3 \\
- \\
1,7\end{array}$ & $\begin{array}{l}0,8- \\
1,5\end{array}$ & $\begin{array}{l}0,2 \\
- \\
0,6\end{array}$ & 0,1 & 0,02 & 0,05 & - & - & Annealing \\
\hline $\mathrm{VCH}$ & 3,3 & 3,0 & $2,7-$ & 1,9 & 1,2 & $0,5-$ & 0,2 & 0,1 & 0,02 & 0,1 & - & - & Annealing \\
\hline
\end{tabular}




\begin{tabular}{|c|c|c|c|c|c|c|c|c|c|c|c|c|c|}
\hline 40 & $\begin{array}{l}- \\
3,8\end{array}$ & $\begin{array}{l}- \\
3,5\end{array}$ & 3,2 & $\begin{array}{l}- \\
2,9\end{array}$ & $\begin{array}{l}- \\
1,7\end{array}$ & 1,5 & $\begin{array}{l}- \\
0,6\end{array}$ & & & & & & \\
\hline $\begin{array}{l}\mathrm{VCH} \\
45\end{array}$ & $\begin{array}{l}3,3 \\
- \\
3,8\end{array}$ & $\begin{array}{l}3,0 \\
- \\
3,5\end{array}$ & $\begin{array}{l}2,7- \\
3,2\end{array}$ & $\begin{array}{l}1,9 \\
- \\
2,9\end{array}$ & $\begin{array}{l}1,3 \\
- \\
1,7\end{array}$ & $\begin{array}{l}0,5- \\
1,5\end{array}$ & $\begin{array}{l}0,3 \\
- \\
0,7\end{array}$ & 0,1 & 0,02 & 0,1 & - & - & $\begin{array}{l}\text { Without } \\
\text { processing }\end{array}$ \\
\hline $\begin{array}{l}\text { VCH } \\
50\end{array}$ & $\begin{array}{l}3,2 \\
- \\
3,7\end{array}$ & $\begin{array}{l}3,0 \\
- \\
3,3\end{array}$ & $\begin{array}{l}2,7- \\
3,2\end{array}$ & $\begin{array}{l}1,9 \\
- \\
2,9\end{array}$ & $\begin{array}{l}2,2 \\
- \\
2,6\end{array}$ & $\begin{array}{l}0,8- \\
1,5\end{array}$ & $\begin{array}{l}0,3 \\
- \\
0,7\end{array}$ & 0,1 & 0,02 & 0,15 & - & - & $\begin{array}{l}\text { Without } \\
\text { processing }\end{array}$ \\
\hline $\begin{array}{l}\mathrm{VCH} \\
60\end{array}$ & $\begin{array}{l}3,2 \\
- \\
3,6\end{array}$ & $\begin{array}{l}3,0 \\
- \\
3,3\end{array}$ & & $\begin{array}{l}2,4 \\
- \\
2,6\end{array}$ & $\begin{array}{l}2,4 \\
- \\
2,8\end{array}$ & & $\begin{array}{l}0,3 \\
- \\
0,7\end{array}$ & 0,1 & 0,2 & 0,15 & 0,3 & 0,4 & Normalization \\
\hline $\begin{array}{l}\text { VCH } \\
70\end{array}$ & $\begin{array}{l}3,2 \\
- \\
3,6\end{array}$ & $\begin{array}{l}3,0 \\
- \\
3,3\end{array}$ & - & $\begin{array}{l}2,6 \\
- \\
2,9\end{array}$ & $\begin{array}{l}2,6 \\
- \\
2,9\end{array}$ & - & $\begin{array}{l}0,4 \\
- \\
0,7\end{array}$ & 0,1 & 0,015 & 0,15 & 0,4 & 0,6 & Normalization \\
\hline $\begin{array}{l}\text { VCH } \\
80\end{array}$ & $\begin{array}{l}3,2 \\
- \\
3,6\end{array}$ & - & - & $\begin{array}{l}2,6 \\
- \\
2,9\end{array}$ & - & - & $\begin{array}{l}0,4 \\
- \\
0,7\end{array}$ & 0,1 & 0,01 & 0,15 & 0,6 & 0,6 & $\begin{array}{l}\text { Double } \\
\text { normalization }\end{array}$ \\
\hline $\begin{array}{l}\mathrm{VCH} \\
100\end{array}$ & $\begin{array}{l}3,2 \\
- \\
3,6\end{array}$ & - & - & $\begin{array}{l}3,0 \\
- \\
3,8\end{array}$ & - & - & $\begin{array}{l}0,4 \\
- \\
0,7\end{array}$ & 0,1 & 0,01 & 0,15 & 0,6 & 0,8 & $\begin{array}{l}\text { Quenching } \\
\text { and tempering }\end{array}$ \\
\hline
\end{tabular}

The structure of samples was studied by methods of optical microscopy on the transverse sections which are cut out from samples in the direction, perpendicular to the movement of the laser beam. The electronic and microscopic analysis has established increase in density of dislocations in a zone of thermal influence.

The depth of laser hardening and the microstructure of the samples were determined by standard metallographic methods after etching in 3\% nitric acid solution in ethyl alcohol. To increase wear resistance applied nitriding with subsequent "shot blasting", in which in the surface layers of the products was created the favorable squeezing tension. Measurements of microhardness was carried on a microthermometry of Lieca VMHT AUTO at a load of $0,98 \mathrm{~N}$, the loading rate of the Vickers pyramid made $40 \mathrm{mkm} / \mathrm{s}$, exposure on loading - $15 \mathrm{~s}$, samplings of two diagonals of a print were made on the computer monitor screen.

Pulse-periodic processing of samples without the absorbing covering at the density of laser radiation up to $3 \mathrm{~kW} / \mathrm{cm}^{2}$ didn't cause a significant hardening of the surface on which traces of laser processing weren't even noticeable.

The zone of laser influence when processing of cast iron in general, consists of the reflow zone and the zone of quenching from the solid state. Melting of the samples surface at pulse-periodic radiation up to a fluence of $20-22 \mathrm{j} / \mathrm{mm}^{2}$ doesn't happen with the absorbing coating, but the increase in fluence up to $28 \mathrm{j} / \mathrm{mm}^{2}$ causes microplane surface of cast iron. The microhardness of the regions melted by laser radiation with fluence 30-40 $\mathrm{j} / \mathrm{mm}^{2}$, increased slightly from $\mathrm{H}=2,5$ to $3,5 \mathrm{HPA}$ in the initial state until $\mathrm{H}=4,5-7,0 \mathrm{HPA}$. The zone of melting has melkodendritny structure with graphite inclusions, the presence of which depends on a fluence of radiation and time of influence. When fluence above 40 $\mathrm{j} / \mathrm{mm}^{2}$ of inclusions of graphite burn out.

The greatest depth of hardening the samples with the absorbing coating is observed at fluence of laser radiation 22-28 j/mm $\mathrm{mm}^{2}$ (figure 1, where $\mathrm{q}, \mathrm{j} / \mathrm{mm}^{2}$ - laser radiation power, $\mathrm{h}, \mathrm{mm}$ - depth of the hardened layer of high-strength cast iron), while the surface melting doesn't occur. At higher fluences, the laser processing leads to melting on the surface. 


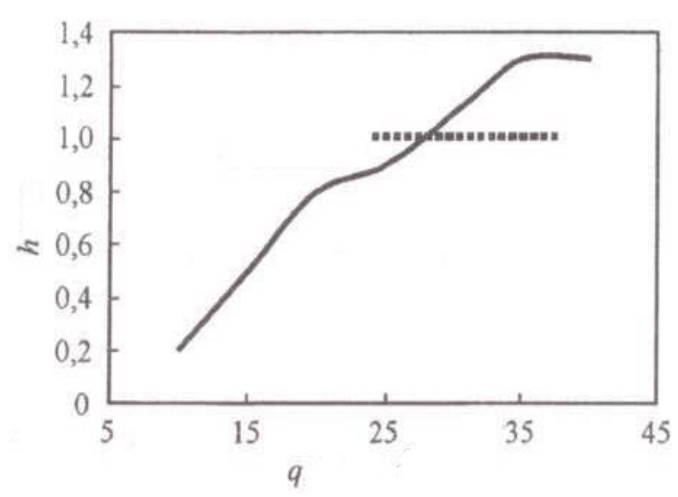

Fig. 1. The dependence of the depth of the hardened layer of high-strength cast iron density of laser radiation power.

Figure 2 (where, h,mm - depth of the hardened layer of high-strength cast iron, $\mathrm{H}_{\mu}, \mathrm{HPa}$ microhardness) shows the distribution of microhardness in depth of the sample after processing with a laser radiation power of $1.0 \mathrm{~kW}$. The speed of movement of the laser spot with a diameter

of $4 \mathrm{~mm}$ on the sample surface made $4 \mathrm{~cm} / \mathrm{s}$, the width of hardened zone $-2,5 \mathrm{~mm}$. It is established that the depth of the hardened layer is approximately $1 \mathrm{~mm}$. Up to depth of 0,5 $\mathrm{mm}$ hardness changes from 10 to $12 \mathrm{HPA}$, followed by a vacation area with a minimum hardness of $\mathrm{H}=4,1-9,8 \mathrm{HPa}$, and then - the main metal, the hardness of which makes 2,53,0 GPA.

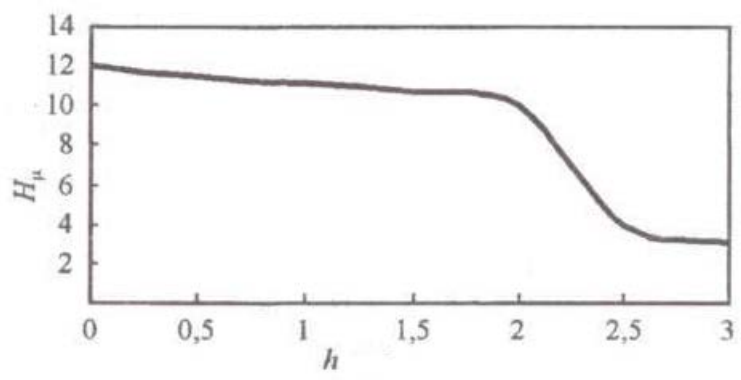

Fig. 2. Distribution of microhardness of high-strength cast iron on the depth of the hardened layer after radiation by the $1 \mathrm{~kW}$ YAG:Nd-laser.

From the data [27], it follows that the size of the hardened zones after radiation of highstrength cast iron $\mathrm{CO}_{2}$-laser makes $0,6-0,8 \mathrm{~mm}$ slightly lower than that after radiation of a solid-state YAG:Nd-laser. The distinction is probably connected with stronger absorption of more short-wave (1,06 microns) of radiation.

\section{Conclusions}

It is experimentally shown the efficiency of use of the solid-state YAG:Nd-laser for hardening of high-strength cast iron $\mathrm{VCH} 70-3$. It is shown that under fluence of laser radiation fluence more than $28 \mathrm{j} / \mathrm{mm}^{2}$ is occured the surface melting of cast iron. The depth of the hardened layer, the microhardness of which is 3-4 times higher than the microhardness of the starting material exceeds $0,5 \mathrm{~mm}$. 


\section{References}

1. Adamka J., Styk J. Increase in the surface hardness of spheroidal cast iron by laser treatment and the effect on tribological propertie. Proc. Eur. Conf. "Laser Treat. Mater." Oberursel, p.235-242 (1987).

2. Belyakov, A. I. Effect of heat processing on the properties of CHSHG / A. I. Belyakov [and others] // Foundry production, No. 12, P. 29-31. (1998).

3. Biryukov V. P. Laser hardening of surfaces of friction of grey cast iron of the scanning beam. Friction and wear, vol. 7, no. 4, pp. 718-721. (1986).

4. Zamyatnin, O. V. Structure and properties of special high-strength cast iron with spherical graphite / O. V. Zamyatin [and others] / Tr. VI"th Intern. Symposium on tribo-fatigue (ISTF 2010), 25 Oct. - 1 Nov. 2010, Minsk / Redkol.: M. A. popular great crane" cov (pred.) [and others], Minsk: BSU, T. 2, P. 79-84. (2010).

5. Zhmailik, V. A. Special high-strength cast iron with spherical graphite as a competitor hardened steel / V. A. Zhmailik [et al.] / Tr. VI-th Intern. Symposium on tribo-fatigue (ISTF 2010), 25 Oct. - 1 Nov. 2010, Minsk / Redkol.: Zhuravkov M. A. (PREV.) [and others], Minsk: BSU, T. 2, P. 73-77. (2010).

6. Gadag S.P., Srinivasan M.N. Surface properties of laser processed ductile iron. Appl.Phys.A, v.63, No.4, p.409-414. (1996).

7. Kornienko, E. N. The development of high-strength cast irons with increased special properties / E. N. Kornienko, M. S. Kolesnikov, Naberezhnye Chelny: Campi, 293p. (1999).

8. Niziev V.G. Influence of beam polarization on laser cutting efficiency / V.G. Niziev, A.V. Nesterov, J. Phys. D: Applied Physics. V. 32. P. 1455-1461 (1999).

9. R.D.Forrest and H.Wolfensberger: Improved ladle treatment of ductile iron by means the tundish cover, AFS Transactions, pp. 421-426. (1980).

10. Safonov A. N. The study of the structure and hardness of surface relatetoproject alloys after melting by laser radiation. MITOM. No. 1, pp. 7-10, (1999).

11. V. T. Zhadan, B. G. Greenberg, V. J. Nikonov, Technology of metals and other structural materials: a textbook for students nemesisaeterna specialties of technical universities, under the General editorship of P. I. Polukhin - 2nd Edition, revised and enlarged. - Moscow : Higher school. - 704 p. (1970).

12. Materials science: Textbook for higher educational institutions. B. N. Arzamasov, I. I. Sidorin, and G. F. Kosolapov e tal. (Under the General editorship of B. N. Arzamasova. - M.: Mashinostroenie, 1986).

13. Molian P.A. Fatigue characteristics of laser surface hardened cast iron. Trans.ASME: J.Eng.Mater.Technol., v.109, No.3, p.179-187. (1987).

14. Sabatino, M. P. High-Strength cast iron in engineering. M. P. Sabatino. - M.: Mashinostroenie, 216 p. (1988).

15. Makarov A.V., Malygina I. Yu., Osintseva A. L. The Influence of laser processing on the structure, wear resistance and fatigue properties of high-strength cast iron. PHAM, №4, p. 46-55. (2006).

16. I. B. Kovsh, M. S. Strekalova. Hardening aluminum by radiation of YAG:Nd-laser with an average power of $0.8 \mathrm{~kW}$. Quantum electronics, No. 2, pp. 151-152. (1994).

17. T.L.Forshey, et al.: Modification of, and production experience with the tundish cover for ductile iron treatment. AFS Transactions, pp. 53-57. (1982). 
18. A. Harnoy, H. Rachoor. Modeling of dynamic friction in lubricated line contacts for precise motion control, Tribology Trans. No.4 601-612. (1995).

19. D. Grevey. Elaboration of functionally graded structures in laser - assisted free-form manufacturing, Laser Technologies in Welding and Materials Processing, p.179-182. (2003).

20. F. Findik. Investigation of explosive welding parameters and their effects on microhardness and shear strength. P. 659-664. (2003).

21. X. Zhang. Effect of shielding conditions on weld properties in underwater local-dry laser welding. Proc. SPIE. No. 4915, p.97-106. (2002).

22. Astapchik S.A. Laser technology in the mechanical engineering and metals industries. S.A. Astapchik, V.S. Golubev, A.G. Maklakov. Minsk: Belorus. science, - 251 p. (2008).

23. Burlachenko O.V., Burov A.M., Ivanov M.V. Advancing the Processing Technologies of the Details of Construction Machinery and Equipment. Proceedings of Moscow State University of Civil Engineering, no. 3, pp. 59-67. (2016).

24. Laser technologies of material processing: modern problems of fundamental research and applied developments. Edited by. V.Ya. Panchenko. M.: Fizmatlit, - 664 p. (2009).

25. Leont'ev P. A., Chekanova N. T., M. G. Khan. Laser surface processing of metals and alloys. M.: metallurgy, - 142 p. (1986).

26. N.N. Rykalin, A.A. Cocora, I.V. Zuev, A.N. Cocora. Laser and electron beam processing of metalls: a handbook. (Engineering, Moscow, 1985).

27. Biryukov V. P., Vlasov D. V., Lesyuk, S. M. Laser hardening of gray and cast iron. Tr. Conf. "The technology of repair, restoration and hardening of details of machines and mechanisms. April 15-18, 2008, St. Petersburg. SPb.: Polytechnic. University, part 2, p. 36-38. (2008). 